\title{
Relation between motor perfomance and physical fitness level of schoolchildren
}

\author{
Renata Capistrano, Elisa Pinheiro Ferrari, Juliano Maestri Alexandre, Raísa Carvalho da Silva, \\ Fernando Luiz Cardoso, Thais Silva Beltrame
}

DOI: http://dx.doi.org/10.7322/jhgd.119261

\begin{abstract}
Introduction: Children with poor motor performance, engage in less vigorous and organized activities, contributing to low scores in physical fitness assessments. However, there is no consensus in the literature about the association between variables.
\end{abstract}

Objective: Evaluate the relationship between motor performance and physical fitness of students between 7 and 10 years old.

Methods: Ninety-eight (98) students enrolled in a public school in Florianópolis, Santa Catarina State, Brazil, participated in this study. For motor evaluation, the Movement Assessment Battery for Children - Second Edition (MABC-2) was used; the assessment of physical fitness was performed using the guidelines of the Brazil Sport Project (PROESP-BR). Data were tabulated in the Statistical Package for Social Sciences (SPSS) for the descriptive statistical analysis (mean, standard deviation, frequency) and inferential analysis (Student's t-test, Mann-Whitney $U$ test, and multiple linear regression test). The significance level was set at $p<0.05$.

Results: The values of the prevalence of motor difficulty and motor difficulty risk were $5.9 \%$ and $13.9 \%$, respectively, and the value for without difficulty of movement was $80.2 \%$. Differences were found for males in the agility tests and explosive strength of the lower limbs $(p<0.05)$, in which the boys with motor difficulty showed lower values. We noticed that abdominal strength, endurance, and agility significantly contributed to explain the variability in motor performance, which together showed a coefficient of determination $\left(\mathrm{R}^{2}\right)$ of 0.13 .

Conclusion: Abdominal strength/endurance and agility contributed significantly in explaining the variability in motor performance. Thus, it is fundamental to encourage involvement in activities that contribute to the increase in motor repertoire reflecting physical fitness.

Key words: motor skills, motor skills disorders, physical fitness, children.

\section{INTRODUCTION}

The motor development in childhood is characterized by the acquisition of a broad range of motor skills, which enable children to develop a vast body domain. These skills are considered basic and are required for basic daily routines and acquisition of more specialized motor skills ${ }^{1}$. During later childhood, comprising the age group of 6 to 10 years, there is a transition of fundamental motor skills to the specialized skills, consisting of the acquisition of the mature pattern of development ${ }^{2}$. However, for the improvement of motor skills, sensory experiences are necessary to encourage the development of locomotive and manipulative movements and stabilizers during these stages of life (fundamental motor phase and specialized motor phase $)^{2}$. In addition, motor experiences contribute in the development of healthy levels of physical fitness ${ }^{3}$.

Physical fitness refers to the ability of the individual to present appropriate physical performance in their daily activities; it can be related to health and fitness, motor skills or athletic abilities ${ }^{4}$. Studies show that children with poor performance in motor domains engage less in vigorous and organized activities, contributing to low scores on physical fitness assessments and ${ }^{3,5}$ motor performance. Children with delayed acquisition of motor skills demonstrate significantly lower values of cardiorespirato-

1 Programa de Pós Graduação em Ciências do Movimento Humano - PPGCMH/ Centro de Ciências da Saúde e do Esporte CEFID/Universidade do Estado de Santa Catarina-UD.

Corresponding author: Renata Capistrano - E-mail: recapis@gmail.com.

Suggested citation: Capistrano R, Ferrari EP, Alexandre JM, Silva RC, Cardoso FL, Beltrame TS. Relation between motor perfomance and physical fitness level of schoolchildren. J Hum Growth Dev. 26(2): 174-180. Doi: http://dx.doi.org/10.7322/jhgd.119261 Manuscript submitted: Mai 12 2016, accepted for publication Mai 162016. 
ry fitness, muscular strength and endurance and anaerobic capacity compared with those with normal development, in addition to a high body fat composition ${ }^{6}$.

Currently, the national literature shows limited studies investigating the association between motor development and physical fitness in children ${ }^{7,8}$, and the results are different, disallowing the confirmation of outcomes found in international research studies, the existence of an association between variables, as well as the direction of the same.

In this way, the objective of this study is to analyze the relationship between motor performance and physical fitness of schoolchildren between 7 and 10 years old.

\section{METHODS}

\section{Characteristics of the Study}

A cross-sectional and descriptive study, with a quantitative approach, was approved by the Ethics Committee under the protocol number 16449913800000118.

\section{Participants}

Study participants were selected in a non-probabilistic way, as the availability of them; there were 98 children in the age group of 7 to 10 years of both genders enrolled in the 1st to 5th year of elementary public school, located in the central region of Florianopolis, Santa Catarina, Brazil. The institution was chosen intentionally due to availability of the school in participating in the research.

The inclusion criteria were as follows: belonging to the established age group (7 to 10 years), presenting an intention to participate voluntarily in the study, having the authorization of parents/guardians through the signature of informed consent, and not having physical problems in the lower limbs or cognitive deficiencies or other limitations that do not allow the completion of assessments, which would be indicated by the educational team in advance or by parents/guardians.

\section{Instruments and Procedures}

The evaluation was carried out through the motor Movement Assessment Battery for Children - Second Edition (MABC-2) $)^{9}$. It is a three-motor test set (Manual Dexterity, Launch and Receive and Balance), suitable for specific age groups: Track one (3 to 6 years) and Track two (7 to 10 years). For each age group differentiated tasks are established according to different levels of complexity. In this study, specifically, Track two (7 to 10 years) was used. The results of the assessment are computed by the MABC- 2 . Total values were compared in the percentiles table, present in the test protocol. Children whose total score is below the 5th percentile should be considered indicative of a motor difficulty; values between the 5th and the 15th percentile indicate that the child has a degree of motor difficulty (risk of motor difficulties), and values above of the 15th percentile values indicate normal motor development.

Physical fitness tests used in this study are part of the implementation of the measures, tests, standards and evaluation criteria of the Brazil Sport Project (PROESP$\mathrm{BR})^{10}$. These tests comprise the assessment of health-relat- ed physical fitness and sports. In the first case, the following aspects were considered: cardiorespiratory endurance, strength/endurance, flexibility and evaluation of body mass and height to calculate body mass index (BMI). The BMI was classified according to World Health Organization (WHO)standards ${ }^{11}$. Aptitude tests for performance in sports were assessed: explosive force of upper and lower limbs, speed, agility and endurance. The results were classified according to the criteria of evaluation of the PROESP-BR ${ }^{10}$.

\section{Statistical analysis}

Descriptive analysis of the variables was completed using statistical indicators of central tendency (mean), uncertainty (standard deviation) and percentage frequencies. The distribution of the data was verified through the Kolmogorov-Smirnov normality test. To compare the scores obtained in tests of physical fitness among children with motor difficulties and those without motor difficulty the Student's t-test was applied for the variables that showed normal distribution: abdominal strength and endurance, flexibility, explosive force of upper limbs and cardiorespiratory fitness. For the other variables, the equivalent nonparametric Mann-Whitney U test was used. In comparison tests, the motor rating was grouped by children with Indicative/Risk of Motor difficulty and Without Motor Difficulty.

To analyze the association of motor performance with the components of physical fitness, the multiple linear regression "stepwise" test was employed. The suitability of the models was tested for a residue analysis and statistics, such as the coefficient of determination $\left(\mathrm{R}^{2}\right)$. It is appropriate to point out that a multiple regression analysis was not performed for the purpose of predicting the dependent variable and to verify the influence of the independent variables in the explanation of the variability of the dependent variable. We used the Statistical Package for Social Sciences (SPSS) version $20.0^{\circledR}$ program for processing and analyzing the data. The significance level was set at $\mathrm{p}<0.05$ for all analyses.

\section{RESULTS}

Ninety-eight (98) children with an average age of 8.97 years $(\mathrm{SD}=1.12)$ participated in this study. With regard to socio-demographic characteristics, 50.5\% were male and $49.5 \%$ female.

Regarding the prevalence of motor difficulty and risk for motor difficulty, the values were $5.9 \%$ and $13.9 \%$, respectively, and the value for without difficulty of movement was $80.2 \%$. For the statistical analysis of motor ratings, were grouped in Indicative/Risk of motor difficulty and normal motor performance.

In general, independent of gender, most children was classified as having a normal motor performance. However, a higher percentage of difficulty, although not significant, was observed in male children (22.4\%) when compared to female children (18.4\%).

Table 1 shows the average values of motor tasks in school contained in MABC-2 according to gender. From 
looking at this table, it is possible to identify that male students demonstrated higher average values only for the domain Launch and Receive, since the female scholars presented higher mean values in the fields Balance and Manual Dexterity. The female scholars also showed greater total test score averages (Table 1).

With respect to the components of physical fitness related to health, the boys showed a higher percentage of inappropriateness $(68.9 \%)$ in the abdominal component compared to the girls (49\%), while for the components flexibility and BMI similar results were found between both: the boys showed (10.9\%) and (31.9\%) of inadequacy on the tests, respectively, and the girls showed (10.2\%) and (31.3\%) of inadequacy on the tests, respectively.

Figure 1 shows the percentages of inadequacy of the components of physical fitness related to performance. As presented in the figure, the male scholars showed a higher prevalence of inadequacy in relation to females for all tests, except for speed (Figure 1).

Table 2 shows the comparison between the scores arising from carrying out the tests and measures to evaluate physical fitness among children with motor difficulties and without motor difficulty, according to gender. Significant differences were observed in males on tests of agility and explosive force of the lower limbs ( $\mathrm{p}<0.05)$, and children with motor difficulties presented lower results. In females, no significant differences were found (Table 2).

As for the parameters found in the multiple linear regression analysis, motor performance is the dependent variable and the components of physical fitness are independent variables. It is possible to see that

Table 1: Characterization of scholars compared to raw scores of each MABC-2 test domain according to gender. Florianópolis, Santa Catarina, Brazil, 2015

\begin{tabular}{lcc}
\hline MABC-2 Items & Male Gender & $\begin{array}{c}\text { Female Gender } \\
\text { Median (SD) }\end{array}$ \\
Dynamic and Static Balance & & \\
Balance on the board preferred leg (seconds) & $23.60(9.03)$ & $25.20(8.27)$ \\
Balance on the other leg (seconds) & $18.40(10.08)$ & $20.88(9.90)$ \\
Walking on the line (correct steps) & $12.50(4.14)$ & $13.46(3.58)$ \\
Jumping mats preferred leg (correct jumps) & $4.92(0.27)$ & $5.00(0.01)$ \\
Jumping mats not preferred leg (correct jumps) & $4.56(0.78)$ & $4.70(0.67)$ \\
Total score & $30.05(7.02)$ & $32.25(5.52)$ \\
Manual Dexterity & & \\
Placing pins preferred hand (seconds) & $33.22(5.48)$ & $33.59(17.32)$ \\
Placing pins not preferred hand (seconds) & $36.38(6.19)$ & $33.61(6.30)$ \\
Passing the cord (seconds) & $31.51(9.04)$ & $28.78(6.75)$ \\
Bicycle track (hits) & $1.36(1.77)$ & $3.00(15.36)$ \\
Total score & $21.66(6.59)$ & $23.51(5.46)$ \\
Launch and Receive & & \\
Receiving with both hands (right) & $7.74(2.52)$ & $10.12(28.24)$ \\
Flipping the bean bag on the target (right) & $6.74(2.31)$ & $6.39(2.14)$ \\
Total score & $21.34(4.88)$ & $18.98(4.22)$ \\
Total Punctuation MABC & & \\
Total test punctuation & $73.05(13.84)$ & $74.74(10.84)$
\end{tabular}

abdominal strength and resistance and agility were the components that contributed significantly in the explanation of the variability in motor performance, which jointly presented a coefficient of determination $\left(\mathrm{R}^{2}\right)$ of 0.13 (Table 3).

\section{DISCUSSION}

The prevalence of difficulty and risk of motor difficulty were $5.9 \%$ and $13.9 \%$, respectively, and the prevalence of without difficulty of movement was $80.2 \%$. The study of Silva and Beltrame ${ }^{12}$ held in Florianópolis, Santa Catarina, Brazil, assessed 406 children, and 11.1\% presented significant difficulty of movement. Souza et al. ${ }^{13}$ identified $11.8 \%$ of children of Manaus, Amazonas, Brazil, with motor difficulties. In Canada 6 , a study evaluated 2,278 children aged between 8 and 10 years and presented $4.5 \%$ of the group with likely motor difficulties. In Green et al. ${ }^{14}$, a study evaluated 4,331 children between
7 and 10 years old and presented $4.4 \%$ of the group with motor difficulties. Most of the research carried out in other countries presented prevalence values lower than those found in the present study, since it showed a variation of $4 \%$ to $8 \%$ in children from 5 to 12 years ${ }^{6}$.

The values for prevalence of motor difficulty may vary according to the population investigated ${ }^{15}$. With this, a bigger standardization in the methods of the study is necessary, as well as the instruments, aiming at a better match to the cultural aspects of each country.

By associating gender and motor rating, we found that the male scholars demonstrated higher average values only for the domain Launch and Receive, since the female scholars presented higher mean values in the fields Balance and Manual Dexterity and also in the total test score. In international studies, reports on motor performance of girls with averages higher than boys can also be found. In a study with 820 children ages 7 to 10 years conducted in the Czech Republic and in the United Kingdom, the girls demonstrated superior motor performance in rela- 


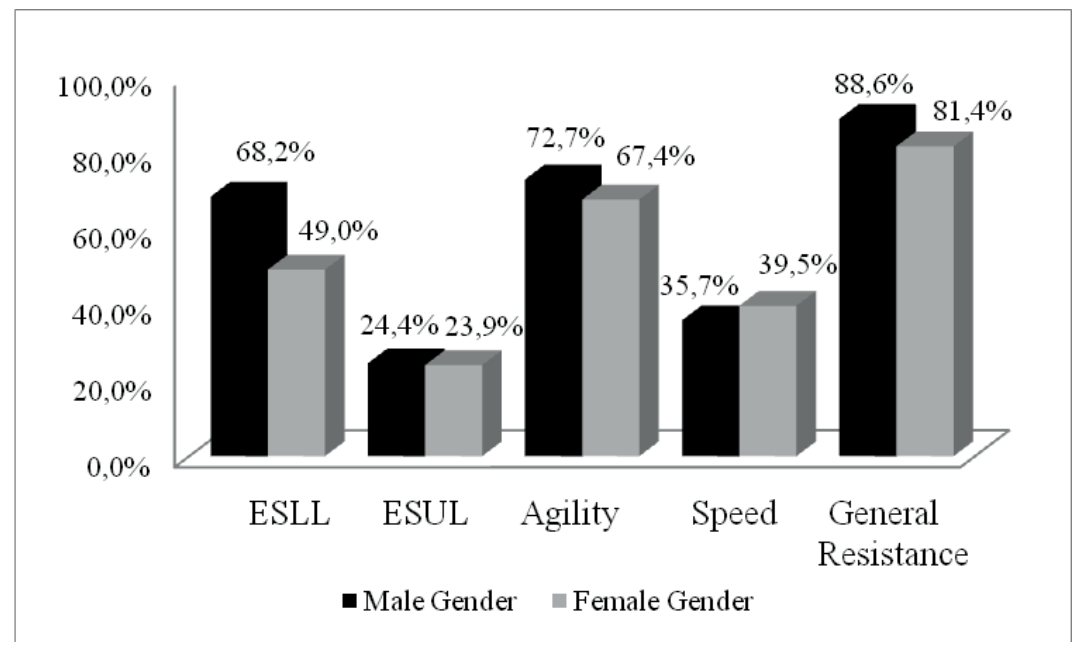

ESLL: Explosive Strength of Lower Limbs; ESUL: Explosive Strength of Upper Limbs

Figure 1: Percentage of inadequacy on tests of physical fitness components related to the performance of students according to genders. Florianópolis, Santa Catarina, Brazil

Table 2: Comparison between scholars with and without motor difficulty in relation to the tests and measures for the evaluation of physical fitness on the PROESP-BR according to gender. Florianópolis, Santa Catarina, Brazil, 2015

\begin{tabular}{|c|c|c|c|c|}
\hline \multirow[t]{2}{*}{ PROESP items } & \multicolumn{2}{|c|}{ Male gender } & \multicolumn{2}{|c|}{ Female gender } \\
\hline & $\begin{array}{c}\text { With MD } \\
\text { Median (SD) }\end{array}$ & $\begin{array}{l}\text { Without MD } \\
\text { Median (SD) }\end{array}$ & $\begin{array}{c}\text { With MD } \\
\text { Median (SD) }\end{array}$ & $\begin{array}{l}\text { Without MD } \\
\text { Median (SD) }\end{array}$ \\
\hline \multicolumn{5}{|l|}{$\begin{array}{l}\text { Physical fitness related } \\
\text { to health }\end{array}$} \\
\hline $\begin{array}{l}\text { Abdominal strength and } \\
\text { resistance (repetitions)* }\end{array}$ & $19.6(5.4)$ & $14.7(5.1)$ & $18.4(3.9)$ & $17.1(7.8)$ \\
\hline Flexibility $(\mathrm{cm})^{\star}$ & $30.1(11.0)$ & $31.4(9.1)$ & $34.3(8.7)$ & $36.6(9.7)$ \\
\hline BMI $\left(\mathrm{kg} / \mathrm{m}^{2}\right)^{\star \star}$ & $18.4(3.9)$ & $17.6(3.2)$ & $16.8(2.0)$ & $18.3(3.4)$ \\
\hline \multicolumn{5}{|l|}{$\begin{array}{l}\text { Physical fitness related } \\
\text { to performance }\end{array}$} \\
\hline $\begin{array}{l}\text { Explosive strength in lower } \\
\text { limbs }(\mathrm{cm})^{\star \star}\end{array}$ & $103.2(14.4)$ & $124.5(18.2)$ & $107.1(20.5)$ & $119.4(21.8)$ \\
\hline $\begin{array}{l}\text { Explosive strength in upper } \\
\text { limbs }(\mathrm{cm})^{*}\end{array}$ & $195.7(35.1)$ & $227.5(43.8)$ & $215.7(40.0)$ & $207.8(38.6)$ \\
\hline Agility (seconds) ${ }^{\star \star}$ & $8.2(0.8)$ & $7.4(1.3)$ & $8.0(1.0)$ & $8.0(0.8)$ \\
\hline Speed (seconds) ${ }^{\star \star}$ & $4.4(0.6)$ & $4.1(0.5)$ & $4.5(0.3)$ & $4.5(0.5)$ \\
\hline 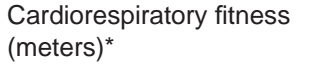 & $649.0(80.6)$ & $748.1(111.1)$ & $695.4(69.0)$ & $657.1(106.6)$ \\
\hline
\end{tabular}

MD: Motor Difficulty; * Student T test; ** Mann Whitney U Test; Bold font: $p<0,05$.

Table 3: Beta value, confidence intervals and the value of the variables that remained in the model. Florianópolis, Santa Catarina, Brazil, 2015

\begin{tabular}{lcccc} 
Variables & BETA & Cl 95\% & p-value & $\mathbf{R}^{2}$ \\
Abdominal strength and resistance & 0.42 & $0.05-0.78$ & 0.03 & 0.13 \\
Agility & -2.31 & $-4.53-1.00$ & 0.04 & \\
\hline
\end{tabular}

Cl 95\%: Confidence interval of 95\%; $\mathrm{R}^{2}$ : adjusted coefficient of determination

tion to the boys, as in the present study; the boys' averages were better only in the area of Psotta et al. ${ }^{16}$. In the United States, an evaluation was conducted of 186 children ages 5 to 14 years; there were no differences found between genders in the tests used, but compared to the girls, the boys had obtained higher averages in the pitching skills ${ }^{17}$. In the literature, in a study made in England, the girls had better motor performance ${ }^{14}$.
In Brazil, different results are found, as in the study done in Minas Gerais by Guedes et al. ${ }^{18}$ with 2,849 scholars ages 6 to 18 years, in which the boys reached best medium-sized motor tests compared to the girls. In São José, Santa Catarina, Brazil, a study of 338 children ages 7 to 10 years did not find significant differences regarding the motor performance between genders ${ }^{19}$. Valentini et al. ${ }^{20}$ assessed 1,587 children ages 4 to 12 years of age in south- 
ern Brazil and found similar results to the present study, in which the boys showed worse performance on tasks of manual dexterity and balance, while the girls showed higher difficulty in launching and receiving skills. These differences between the studies are justified due to methodological differences.

The differences between the genders with regard to motor performance can be explained by cultural factors, environmental requirements and opportunities of for motor experiences, since boys and girls, culturally, are encouraged to participate in different activities in their everyday lives, requiring the distinctive development of skills to fulfill the tasks ${ }^{21}$.

Among the components assessed in relation to physical fitness in Europe 10,302 children of both genders in eight European countries (Sweden, Germany, Hungary, Italy, Cyprus, Spain, Belgium and Estonia) were evaluated; the researchers measured agility, flexibility, speed, strength of upper and lower limbs and aerobic resistance. The authors found that boys showed better performance than girls in speed trials, agility, muscular strength and aerobic endurance. The girls, in turn, performed better than boys in balance and flexibility ${ }^{22}$.

In Brazil, 3,145 children ages 7 to 16 years in São Paulo ${ }^{23}$ were evaluated; the results showed that the boys have greater abdominal strength and aerobic endurance compared to girls, and the girls, in turn, showed better flexibility of the trunk in the sit and reach test. In the present study, the girls showed performance that is more satisfactory in tests of agility, flexibility, explosive force of the lower limbs and aerobic resistance than boys.

The components of physical fitness, endurance and agility contributed significantly to the explanation of motor performance in school children $\left(\mathrm{R}^{2}=0.13\right)$. Currently, studies relating motor performance and physical fitness use just the averages of the components of physical fitness and motor performance in relation to the gender of the participants, or even individuals that present motor difficulty or not. The study of Hiraga et al. ${ }^{24}$, held in Brazil in the city of Rio Claro, São Paulo State with 64 children ages
7 to 10 years old, set out to examine the components of physical fitness in children with motor difficulties and with typical development (DT). Children with motor difficulties presented smaller lower-sized components of physical fitness when compared with children with DT. In another Brazilian study, 127 children were evaluated with respect to motor performance, and 16 were classified with motor difficulties. The analyses have shown that typical children presented better medium-sized components of physical fitness compared with children with motor difficulties ${ }^{8}$.

In Greece, 69 children between 6 and 11 years old were also evaluated for performance and physical fitness. The results showed that typical children present better better medians, if compared to children with motor difficulty in the components of physical fitness ${ }^{5}$.

All these studies are extremely important in understanding the relationship between motor performance and physical fitness; however, understanding which components of physical fitness contribute most to the variation in motor performance is also relevant because the literature points out that low motor performance and low performance in the components of physical fitness are related ${ }^{8}$.

Although the present study moves in the direction of the relationship between motor performance and physical fitness and the exploitation of these variables between the genders, the study also has some limitations such as having a cross-sectional design, which does not verify the temporal sequence of the association between the variables investigated, and the reduced number of children investigated, which does not allow for the extrapolation of the data. However, as a result of the evaluation of children through two batteries of tests and the small number of children investigated, this study contributes to an increased awareness and consolidation of the theme.

Thus, abdominal strength/resistance and agility were the components that contributed significantly to the explanation of the variability in motor performance, and most of the schoolchildren evaluated presented normal motor development.

\section{REFERENCES}

1. Santos S, Dantas L, Oliveira JA. Desenvolvimento motor de crianças, de idosos e de pessoas com transtornos da coordenação. Rev Paul Educ Fís. 2004;18(especial):33-44.

2. Gallahue DL, Ozmun JC, Goodway DJ. Compreendendo o desenvolvimento motor: bebês, crianças, adolescentes e adultos. 7 ed. São Paulo: Artmed; 2013; p. 21-41.

3. Batey CA, Missiuna CA, Timmons BW, Hay JA, Faught BE, Cairney J. Self-efficacy toward physical activity and the physical activity behavior of children with and without Developmental Coordination Disorder. Hum Mov Sci. 2014;36:258-71. DOI: http://dx.doi.org/10.1016/j.humov.2013.10.003

4. Böhme MTS. Relação entre aptidão física, esporte e treinamento esportivo. Rev Bras Ciênc Mov. 2003;11(3):97-104.

5. Lifshitz N, Raz-Silbiger S, Weintraub N, Steinhart S, Cermak SA, Katz N. Physical fitness and overweight in Israeli children with and without developmental coordination disorder: gender differences. Res Dev Disabil. 2014;35(11):2773-80. DOI: http://dx.doi.org/10.1016/j.ridd.2014.07.020

6. Joshi D, Missiuna C, Hanna S, Hay J, Faught BE, Cairney J. Relationship between BMI, waist circumference, physical activity and probable developmental coordination disorder over time. Hum Mov Sci. 2015;40:237-47. DOI: http://dx.doi.org/10.1016/j.humov.2014.12.011

7. Krebs RJ, Duarte MG, Nobre GC, Nazario PF, Santos JOL. Relação entre escores de desempenho motor e aptidão física em crianças com idades entre 07 e 08. Rev Bras Cineantropom. Desempenho Hum. 2011;13(2):94-99. DOI: http://dx.doi.org/10.5007/1980-0037.2011v13n2p94 
8. Santos MMA, Ribeiro SML, Pellegrini AM, Rocha PRH, Hiraga CY. Crianças com dificuldades motoras apresentam baixos níveis de aptidão física? Motriz: Rev Educ Fis. 2012;18(4):748-56. DOI: http://dx.doi. org/10.1590/S1980-65742012000400013

9. Henderson SE, Sugden DA, Barnett AL. Movement Assessment Battery for Children - 2. Londres: Pearson Assessment; 2007; p. 41-183.

10. Gaya A, Lemos A, Gaya A, Teixeira D, Pinheiro E, Moreira R. Projeto Esporte Brasil: PROESP-Br: manual de testes e avaliação: versão 2012. Porto Alegre: UFRGS /CNPq / Ministério do Esporte; 2012.

11. Organização Mundial de Saúde (OMS). Classificação do estado nutricional para adolescentes de 10 a 19 anos, 2007. [cited 2014 May 30] Available from: <http://nutricao.saude.gov.br/>

12 Silva J, Beltrame TS. Desempenho motor e dificuldades de aprendizagem em escolares com idades entre 7 e 10 anos. Motricidade. 2011;7(2):53-64.DOI: http://dx.doi.org/10.6063/motricidade.7(2).111

13. Souza C, Ferreira L, Catuzzo MT, Corrêa UC. O teste ABC do movimento em crianças de ambientes diferentes. Rev Port. Cienc.Desp. 2007;7(1):36-47.

14. Green D, Lingam R, Mattocks C, Riddoch C, Ness A, Emond A. The risk of reduced physical activity in children with probable Developmental Coordination Disorder: a prospective longitudinal study. Res. Dev. Disabil. 2011;32(4):1332-42. DOI: http://dx.doi.org/10.1016/j.ridd.2011.01.040

15. Junaid K, Harris SR, Fulmer KA, Carswell A. Teachers' Use of the MABC Checklist to Identify Children with Motor Coordination Difficulties. Pediatr Phys Ther. 2000;12(4):158-63. DOI: http://dx.doi. org/10.1097/00001577-200001240-00003

16. Psotta R, Hendl J, Fromel K, Lehnert M. The second version of the Movement Assessment Battery for Children: A comparative study in 7-10 year old children from the Czech Republic and the United Kingdom. Acta Univ Palacki Olomuc Gymn. 2012;42(4):19-27. DOI: http://dx.doi.org/10.5507/ag.2012.020

17. Butterfield SA, Angell RM, Mason CA. Age and sex differences in object control skills by children ages 5 to 14. Percept Mot Skills. 2012;114(1):261-74. DOI: http://dx.doi.org/10.2466/10.11.25.PMS.114.1.261-274

18. Guedes DP, Neto JTM, Silva AJ. Desempenho motor em uma amostra de escolares brasileiros. Motricidade. 2011;7(2):25(14):25-38. DOI: http://dx.doi.org/10.6063/motricidade.7(2).108

19. Silva JD, Capistrano R, Beltrame TS, Alexandre JM. Desempenho motor e senso de autoeficácia de escolares do ensino fundamental. Psicol. Teor. 2014;16(2):122-130. DOI: http://dx.doi.org/10.15348/19806906/psicologia.v16n2p122-130

20. Valentini NC, Coutinho MTC, Pansera SM, Santos VAP, Vieira JLL, Ramalho MH, et al. Prevalence of motor deficits and developmental coordination disorders in children from South Brazil. Rev Paul Pediatr. 2012;30(3):377-84. DOI: http://dx.doi.org/10.1590/S0103-05822012000300011

21. Coutinho MTC, Spessato BC, Valentini NC. Transtorno do desenvolvimento da coordenação: prevalência e dificuldades motoras de escolares da cidade de Porto Alegre. Congresso Brasileiro de Ciências do Esporte. Anais. [cited 2014 May 30] Available from: <http://cbce.tempsite.ws/congressos/index.php/ XVII_CONBRACE/2011/schedConf/presentations>.

22. De Miguel-Etayo P, Gracia-Marco L, Ortega FB, Intemann T, Foraita R, Lissner L, et al. Physical fitness reference standards in European children: the IDEFICS study. Int J Obesity. 2014;38(Suppl 2):57-66. DOI: http://dx.doi.org/10.1038/ijo.2014.136

23. Luguetti CN, Ré AHN, Böhme MTS. Indicadores de aptidão física de escolares da região centro-oeste da cidade de São Paulo. Rev Bras Cineantropom. Desempenho Hum. 2010;12(5):331-7. DOI: http:// dx.doi.org/10.5007/1980-0037.2010v12N5P331 24. Hiraga CY, Rocha PRH, Ferracioli MDC, Gama DT, Pellegrini AM. Physical fitness in children with probable developmental coordination disorder and normal body mass index. Rev Bras Cineantropom. Desempenho Hum. 2014;16(2):182-90. DOI: http://dx.doi. org/10.5007/1980-0037.2014v16n2p182

This article is distributed under the terms of the Creative Commons Attribution 4.0 International License (http://creativecommons.org/licenses/by/4.0/), which permits unrestricted use, distribution, and reproduction in any medium, provided you give appropriate credit to the original author(s) and the source, provide a link to the Creative Commons license, and indicate if changes were made. The Creative Commons Public Domain Dedication waiver (http://creativecommons.org/publicdomain/zero/1.0/) applies to the data made available in this article, unless otherwise stated. 


\section{Resumo}

Introdução: Crianças com fraco desempenho motor, podem se envolver em atividades menos vigorosas e organizadas, contribuindo para a baixa pontuação nas avaliações de aptidão física. No entanto, não há consenso na literatura sobre a associação entre variáveis.

Objetivo: Avaliar a relação entre o desempenho motor e aptidão física dos alunos com idade entre 7 e 10 anos de idade.

Método: 98 alunos matriculados em uma escola pública de Florianópolis/SC participaram deste estudo. Para avaliação motora foi utilizada a bateria de avaliação Movimento para Crianças Segunda Edição - MABC-2; a avaliação da aptidão física foi realizada pelo Manual de Aplicação do Projeto Esporte Brasil - PROESP-BR. Os dados foram tabulados no programa Statistical Package for Social Sciences - SPSS, assiting a análise estatística descritiva (média, desvio padrão, freqüência) e inferencial (teste $t$ de Student, teste de Mann-Whitney, teste de regressão linear múltipla). O nível de significância foi fixado em $p<0,05$.

Resultados: Os valores de prevalência de dificuldade motora e de risco para dificuldade motora foram de 5,9\% e 13,9\%, respectivamente, e sem dificuldade de movimentação foi de $80,2 \%$. Foram encontradas diferenças para o sexo masculino nos testes de agilidade, força explosiva dos membros inferiores ( $p<0,05$ ), em que os meninos com dificuldade motora apresentaram valores mais baixos. Notamos que a força e resistência abdominal e agilidade foram os componentes que contribuíram de forma significativa para explicar a variabilidade no desempenho motor, que, juntos, mostrou um coeficiente de determinação $\left(R^{2}\right)$ de 0,13 .

Conclusão: O abdominal força / resistência e agilidade foram os componentes que contribuíram de forma significativa para explicar a variabilidade no desempenho do motor. Assim, é fundamental para incentivar o envolvimento em actividades que contribuem para o aumento do repertório motor refletindo sobre a aptidão física.

Palavras-chave: habilidades motoras, perturbações habilidades motoras, aptidão física, crianças. 